\title{
Inhibitory effect of survivin-targeting small interfering RNA on gastric cancer cells
}

\author{
Y.H. Li, M. Chen, M. Zhang, X.Q. Zhang, S. Zhang, C.G. Yu, \\ Z.M. Xu and X.P. Zou \\ Department of Gastroenterology, \\ The Affiliated Drum Tower Hospital of Nanjing University, \\ Medical School, Nanjing, China \\ Corresponding author: X.P. Zou \\ E-mail: yhdoccn@yeah.net \\ Genet. Mol. Res. 13 (3): 6786-6803 (2014) \\ Received June 5, 2013 \\ Accepted November 12, 2013 \\ Published August 28, 2014 \\ DOI http://dx.doi.org/10.4238/2014.August.28.22
}

\begin{abstract}
A pair of inverted repeated sequences of the gene survivin was designed for stable double-stranded RNA establishment. After stable transfection, the biological behaviors of gastric cancer cells were observed. The interference rates of survivin-targeting siRNA (siRNA-survivin) in BGC823, MKN45, SGC7901, and cisplatin-resistant SGC7901 groups were $55.363 \pm 3.974,71.433 \pm 3.774,69.433 \pm 7.336$, and $76.767 \pm$ $3.541 \%$, respectively, compared with those in the control group. After siRNA-survivin interference, survivin protein expression noticeably decreased, apoptotic rates markedly increased, and cell proliferation was inhibited to varying degrees. Mitochondrial cytochrome $\mathrm{C}$ protein expression decreased and the levels of cytoplasmic cytochrome $\mathrm{C}$ and caspase-3 increased, which showed significant differences compared with values before transfection. pRNA-shSU eukaryotic expression vectors were constructed. After plasmid transfection, green fluorescent protein expression increased and survivin protein expression noticeably increased in BGC823 and SGC7901. siRNA-survivin promotes GC cell apoptosis and inhibits cell proliferation by downregulating survivin mRNA and protein expression. The underlying mechanisms
\end{abstract}


are correlated with a decrease in mitochondrial cytochrome $\mathrm{C}$ and cytoplasmic cytochrome C and caspase-3.

Key words: Survivin; Gastric cancer; Small interfering RNA; Apoptosis

\section{INTRODUCTION}

Gastric cancer (GC), one of the most common malignancies in China, is characterized by a pathological process involving multiple factors, genes, and links. GC has the fourth highest incidence rate and the second highest fatality rate among malignancies worldwide (Brummmelkamp et al., 2002). In China, it has the highest incidence rate among various tumors, and approximately 170,000 patients die of this condition annually, accounting for nearly $1 / 4$ of malignancy-related deaths. Therefore, it is a serious life-threatening disease. GC occurs at any age, but more commonly between 40 and 60 years. Males are more affected than females with a 2:1 gender ratio. Current therapies for GC, such as therapeutic endoscopy, surgery, radiotherapy, chemotherapy, interventional therapy, biotherapy, and immunotherapy fail to achieve satisfactory results. The five-year survival rate of GC patients is below $20 \%$ (Li et al., 1998).

The gene survivin was first isolated through screening by hybridization of the human genomic library using effector cell protease receptor-1 (EPR-1) cDNA by Ambrosini et al. (1997). Since this gene enables to prolong cell growth, it was so named. survivin expression has apparent characteristics of cell cycle and tissue distribution. Its overexpression may lead to tumorigenesis with uncontrolled cell cycle progression. Conversely, cells lacking survivin have abnormal cell division (Van Antwerp et al., 1998; Vaira et al., 2007).

The survivin-encoded product survivin is a new member of the inhibitor of apoptosis (IAP) family and has multiple functions. It inhibits cell apoptosis, promotes cell transformation, participates in cell division, vascularization, and the generation of tumor cell drug resistance, and so on. It enters cells under the stimulation of the Fas gene and cell proliferation, wherein it binds the cyclin $\mathrm{CDK} 4$, leading to $\mathrm{CDK} 2 /$ cyclin $\mathrm{E}$ activation and $\mathrm{Rb}$ phosphorylation. These processes promote DNA replication and shorten the G1/S course (Sommer et al., 2003). Furthermore, the formation of the survivin/CDK4 complex allows $\mathrm{p} 21 \mathrm{wafl} / \mathrm{cip} 1$ to be released from the $\mathrm{p} 21 \mathrm{waf1} / \mathrm{cip} 1-\mathrm{CDK} 4$ complex. The released $\mathrm{p} 21 \mathrm{waf} 1 / \mathrm{cip} 1$ then interacts with procaspase-3 to prime the inactivation of caspase-3, thereby inhibiting Fas-mediated apoptosis. Survivin serves as the direct repressor of caspase- 3 and caspase- 7 and blocks the process of cell apoptosis (You et al., 2004).

Survivin is extensively expressed in embryonic tissues, such as the kidneys, brain, and lungs. In healthy adults, it is only weakly expressed in the thymus and genital glands. However, it has extensive expression in most malignant tumor tissues. These characteristics of survivin suggest that survivin may stay in an out-of-control status during tumorigenesis. Nakamura found that survivin is much more highly expressed in GC tissue than atrophic gastritis tissue, but not expressed in normal gastric tissue (Nakamura et al., 2004). Its expression level negatively correlates with patients' survival. A lower differentiation level of GC tissue indicates higher survivin expression and poorer prognosis (Fortugno et al., 2002). Our previous study proved that survivin expression is noticeably increased in GC tissue, and that survivin overexpression is correlated with the histological grade and pathological stage of GC (Altieri, 2003a).

In this study, we observed the biological behaviors of tumor cells after transfecting 
survivin-targeting (siRNA-survivin) into these cells. We also designed and synthesized a pair of inverted repeated sequences of survivin with the expectation to provide a new method for GC gene therapy.

\section{MATERIAL AND METHODS}

\section{Cell strain screening and culture}

GC BGC823, MKN45, SGC7901, and cisplatin-resistant SGC7901 strains were selected as the subjects. They were supplied by Dr. Min Chen at the Nanjing Drug Tower Hospital affiliated to Nanjing University Medical School. The strains were cultured in RPMI-1640 medium (GIBCO, USA) supplemented with 10\% fetal bovine serum (Zhejiang Tianhang Biology Technology Co., Ltd., China), $100 \mathrm{U} / \mathrm{mL}$ penicillin, and $100 \mu \mathrm{g} / \mathrm{mL}$ streptomycin in $5 \% \mathrm{CO}_{2}$ at $37^{\circ} \mathrm{C}$ using the adherence method. When the cells nearly reached confluence, they were digested with $0.25 \%$ pancreatin for subculture 2-3 times per week. Cells in logarithmic phase were harvested.

\section{Mitochondrial protein extraction}

The cells were washed and counted. About $5 \times 10^{7}$ cells were added to $1.5 \mathrm{~mL}$ of prechilled Lysis Buffer-1 for cell resuspension. They were ground at $0-4^{\circ} \mathrm{C}$ and then centrifuged at $800 \mathrm{rpm}$ for $5 \mathrm{~min}$ at $4^{\circ} \mathrm{C}$. About $0.5 \mathrm{~mL}$ homogenized supernatant was carefully added to another pre-chilled centrifuge tube containing $0.5 \mathrm{~mL}$ Medium Buffer. Centrifugation at 15,000 $\mathrm{rpm}$ at $4^{\circ} \mathrm{C}$ was performed for $10 \mathrm{~min}$. After centrifugation, cytoplasmic components were contained in the supernatant and mitochondria precipitated. The supernatant was transferred to another centrifuge tube. The mitochondrial pellets were resuspended with $0.2 \mathrm{~mL}$ Wash Buffer and then centrifuged at $15,000 \mathrm{rpm}$ at $4^{\circ} \mathrm{C}$ for $10 \mathrm{~min}$. The supernatant was discarded.

Total protein extraction and quantitation were performed. About $10 \mu \mathrm{L}$ phosphatase inhibitor, $1 \mu \mathrm{L}$ proteinase inhibitor, and $5 \mu \mathrm{L} 100 \mathrm{mM}$ PMSF were applied per mL cold Lysis Buffer and then shaken. The mixture was allowed to stand for a few minutes on ice. About $20 \mu \mathrm{L}$ pelleted mitochondria were added to $200 \mu \mathrm{L}$ prepared Lysis Buffer and then softly shaken at $4^{\circ} \mathrm{C}$ for $15 \mathrm{~min}$. The mixture was centrifuged at $14,000 \mathrm{rpm}$ at $4^{\circ} \mathrm{C}$ for $15 \mathrm{~min}$. The supernatant was total extracted protein. Protein quantitation was performed using the Bradford (bicinchoninic acid) method. The product was stored at $-70^{\circ} \mathrm{C}$.

\section{Western blot analysis}

Total protein extraction and quantitation were performed using the previously described methods. The extraction products were subjected to SDS-PAGE electrophoresis for one to two hours. The separation gels of the proteins with corresponding molecular weights were taken and blocked in 5\% skimmed milk for $1 \mathrm{~h}$ and then incubated with primary antibodies (1:1000 dilution; Abcam, USA) overnight. $\beta$-actin (1:3000 dilution; Multi-Sciences, China) was used as the internal reference. After TBST washing, the samples were incubated with secondary antibodies (KPL, USA) for $2 \mathrm{~h}$. Photographs were taken and scanned using a gel or photograph transient display system. Optical density (OD) values of the target bands were analyzed using the Quantity One image analysis software. The ratios between the OD of the 
target bands and those of their corresponding $\beta$-actin were calculated.

\section{Immunofluorescence}

The cells were inoculated on gelatin-pretreated cover slips in a 6-well culture plate. After handing, they were washed twice with PBS and fixed in cold acetone at $4^{\circ} \mathrm{C}$ for $30 \mathrm{~min}$. After washing, they were blocked in goat serum (Boster, China) for $1 \mathrm{~h}$ and then incubated with primary antibodies $\left(1: 200\right.$; Abcam, USA) at $4^{\circ} \mathrm{C}$ overnight. After PBS washing, anti-rabbit fluorescence-labeled secondary antibody (Molecular Probe, USA) was applied for $2 \mathrm{~h}$ of incubation. DAPI solution was applied for 5 min of nuclear staining. Outcomes were observed under a fluorescence microscope within $1 \mathrm{~h}$. Photographs were taken.

\section{Real-time polymerase chain reaction (PCR)}

The upstream and downstream primers of survivin were 5'-GGC ATG GGT GCC CCG ACG TT-3' and 5'-AGA GGC CTC AAT CCATGG CA-3' and those of GAPDH were 5'-CAT CTT CCA GGA GCG AGA-3' and 5'-TGT TGT CAT ACT TCT CA-3'. RNA extraction, reverse transcription, and PCR detection were performed according to kit instructions (TaKaRa, Japan). Real-time PCR was conducted on an ABI7500 real-time quantitative PCR instrument. The reaction system with a volume of $20 \mu \mathrm{L}$ contained $2 \mu \mathrm{L}$ first-strand cDNA, $10 \mu \mathrm{L}$ SYBR Premix Ex TaqTM (2X), $0.4 \mu \mathrm{L}$ ROX Reference Dye II (50X), $0.4 \mu \mathrm{L}$ survivin upstream primer, $0.4 \mu \mathrm{L}$ survivin downstream primer, and $6.8 \mu \mathrm{L}$ deionized water. The amplification conditions consisted of $95^{\circ} \mathrm{C}$ for $30 \mathrm{~s}$, followed by 40 cycles of $95^{\circ} \mathrm{C}$ for $3 \mathrm{~s}, 60^{\circ} \mathrm{C}$ for $30 \mathrm{~s}, 95^{\circ} \mathrm{C}$ for $15 \mathrm{~s}, 60^{\circ} \mathrm{C}$ for $1 \mathrm{~min}$, and $95^{\circ} \mathrm{C}$ for $15 \mathrm{~s}$. The $2^{-\Delta \Delta \mathrm{Ct}}$ method was used for outcome analysis. The amplification system of GAPDH was consistent with that of survivin.

\section{Cell apoptosis detection}

The digested cell suspension was cultured on a 6-well plate with $1 \mathrm{~mL}$ (containing about $2 \times 10^{5}$ cells) in each well. They were further cultured with PPI or chemotherapeutic drugs according to requirements. The suspended cells were centrifuged at $2000 \mathrm{rpm}$ for 5 min and collected, whereas the adherent cells were subjected to EDTA-free trypsinization (the digestion time should not be too long in case of false positivity) and then collected. They were washed twice with $0.01 \mathrm{M} \mathrm{PBS}$ and then centrifuged at $2000 \mathrm{rpm}$ for $5 \mathrm{~min}$. About 1-5 x $10^{5}$ cells were collected. Binding Buffer $(500 \mu \mathrm{L})$ and Annexin V-FITC $(5 \mu \mathrm{L}$; KeyGENE Biotech, China) were added and mixed. About $5 \mu \mathrm{L}$ PI was added and shaken. The mixture was allowed to react away from light at room temperature for 5-15 min. Flow cytometry was performed within $1 \mathrm{~h}$.

\section{Cell proliferation ratio detection}

A 96-well plate was used for cell proliferation experiments with about 8000 cells per $100 \mu \mathrm{L}$ of the culture solution in each well (the exact cell number was determined by their size and proliferation ratio). The cells were cultured in accordance with the experimental requirements. Meanwhile, they were stimulated with $0-10 \mu \mathrm{L}$ specific drugs. 
About $10 \mu \mathrm{L}$ CCK-8 solution (KeyGENE, China) were added to each well with a total culture volume of $100 \mu \mathrm{L}$. Wells containing corresponding volumes of cell culture solution and CCK-8 solution rather than cells were taken as blank controls. For drug interference detection, those containing corresponding volumes of cell culture, drug, and CCK-8 solutions were taken as blank controls. The cells were continuously grown for $0.5-4 \mathrm{~h} \mathrm{(1}$ $\mathrm{h}$ was enough in most situations). Culture time spans were determined according to cell type and density. Microplate assays were performed at $0.5,1,2$, and $4 \mathrm{~h}$, respectively, and then the most appropriate detection time point was determined. Absorbance $(A)$ was read at $450 \mathrm{~nm}$.

\section{siRNA-survivin}

According to the gene sequence of survivin, two specific siRNA and two nonsense siRNA were designed and synthesized in vitro (aided by the Thermo-Fisher Company) as follows: survivin siRNA (+): 5'-GGA CCA CCG CAU CUC UAC AdTdT-3' and 3'-dTdTC CUG GUG GCG UAG AGA UGU-5'; control survivin siRNA (-): 5'-CGU ACG CGG AAU ACU UCG AdTdT-3' and 3'-dTdTG CAU GCG CCU UAU GAA GCU-5'.

The cells in logarithmic phase were digested and counted 1 day before transfection. They were inoculated with BGC823, MKN45, SGC7901, and cisplastin-resistant SGC7901 strains according to $8 \times 10^{3}$ cells/well on a 96-well plate and $2 \times 10^{5}$ cells/well on a 24 -well plate overnight. Cell strain transfection was performed using Lipofectamine 2000 liposomes (Invitrogen, USA) bound with $100 \mathrm{nM}$ siRNA. The cells were collected for RNA interference effects using immunoblotting, immunofluorescence, and real-time PCR.

\section{Vector construction}

Based on the coding region of survivin 5'-GGA CCA CCG CAT CTC TAC-3', two DNA sequences were synthesized by Sangon Biotech (China) as follows:

1) 5'-GAT CCG GGA CCA CCG CAT CTC TAC ATC AAG AGT GTA GAG ATG CGG TGG TCC TTT TTT GAA TTC A-3'

2) 5'-AGC TTG AAT TCA AAA AAG GAC CAC CGC ATC TCT ACA CTC TTG ATG TAG AGA TGC GGT GGT CCC G-3'

About 10 pmol of each of the above mentioned primers were added to annealing buffer solution (containing $10 \mathrm{mM}$ Tris, $\mathrm{pH} 8.0,1 \mathrm{mM}$ EDTA, and $10 \mathrm{mM} \mathrm{NaCl}$ ) and the mixture then placed in a water bath at $95^{\circ} \mathrm{C}$ for $5 \mathrm{~min}$. A centrifuge tube was placed in $1 \mathrm{~L}$ of water at $95^{\circ} \mathrm{C}$, and the water was cooled gradually to room temperature. DNA vectors at $1 \mu \mathrm{L}(1 \mu \mathrm{g})$ were digested in digestion buffer ( $3 \mu \mathrm{L} 10 \mathrm{X} \mathrm{K}$ buffer, $24 \mu \mathrm{L}$ ddH $_{2} \mathrm{O}, 1 \mu \mathrm{L}$ Bam HI, and $1 \mu \mathrm{L}$ HindIII) for $2 \mathrm{~h}$ and then purified with agarose gels. The digested pRNAT-U6.3 vectors at $5 \mu \mathrm{L}$, the annealed fragments at $5 \mu \mathrm{L}, 10 \mathrm{X}$ ligation buffer at $2 \mu \mathrm{L}$, and $\mathrm{ddH}_{2} \mathrm{O}$ at $7 \mu \mathrm{L}$ were ligated with $1 \mu \mathrm{L} \mathrm{T}_{4}$ DNA ligase at $16^{\circ} \mathrm{C}$ overnight. The ligated products at $10 \mu \mathrm{L}$ were applied to $100 \mu \mathrm{L}$ DH5 $\alpha$ competent cells. They were subjected to $0^{\circ} \mathrm{C}$ for $30 \mathrm{~min}, 42^{\circ} \mathrm{C}$ for $2 \mathrm{~min}$, and $0^{\circ} \mathrm{C}$ for $3 \mathrm{~min}$. Next, $1 \mathrm{~mL} 37^{\circ} \mathrm{C}$-preheated LB medium was added for 30 -min homoisothermal culture at $37^{\circ} \mathrm{C}$. The obtained product was spread on an $\mathrm{Amp}^{\mathrm{r}}$ plate. Monoclonal bacteria were cultured using small-volume $(2 \mathrm{~mL})$ culturing. Plasmids were extracted using a plasmid mini kit. They were respectively digested with BamHI, EcoRI, and HindIII and then subjected to electrophoresis. 


\section{Statistical analysis}

All measurement data are reported as means \pm standard error. Statistical analysis was carried out by the SPSS 13.0 software. One-factor ANOVA was used to compare between groups. Differences of $\mathrm{P}<0.05$ were considered to be statistically significant.

\section{RESULTS}

\section{survivin mRNA expression}

The interference effect of siRNA-survivin interference on survivin mRNA expression was detected using real-time PCR. As shown in Figure 1, siRNA-survivin successfully interfered with survivin mRNA expression in all four cell strains. The interference efficiency of negative siRNA in BGC823 was set at 1. The interference efficiency of siRNA-survivin in BGC823, MKN45, SGC7901, and cisplatin-resistant SGC7901 was 55.363 $\pm 3.974,71.433$ $\pm 3.774,69.433 \pm 7.336$, and $76.767 \pm 3.541 \%$, respectively. These findings indicated that siRNA-survivin had an inhibitory effect on survivin mRNA expression in all four GD cell strains.

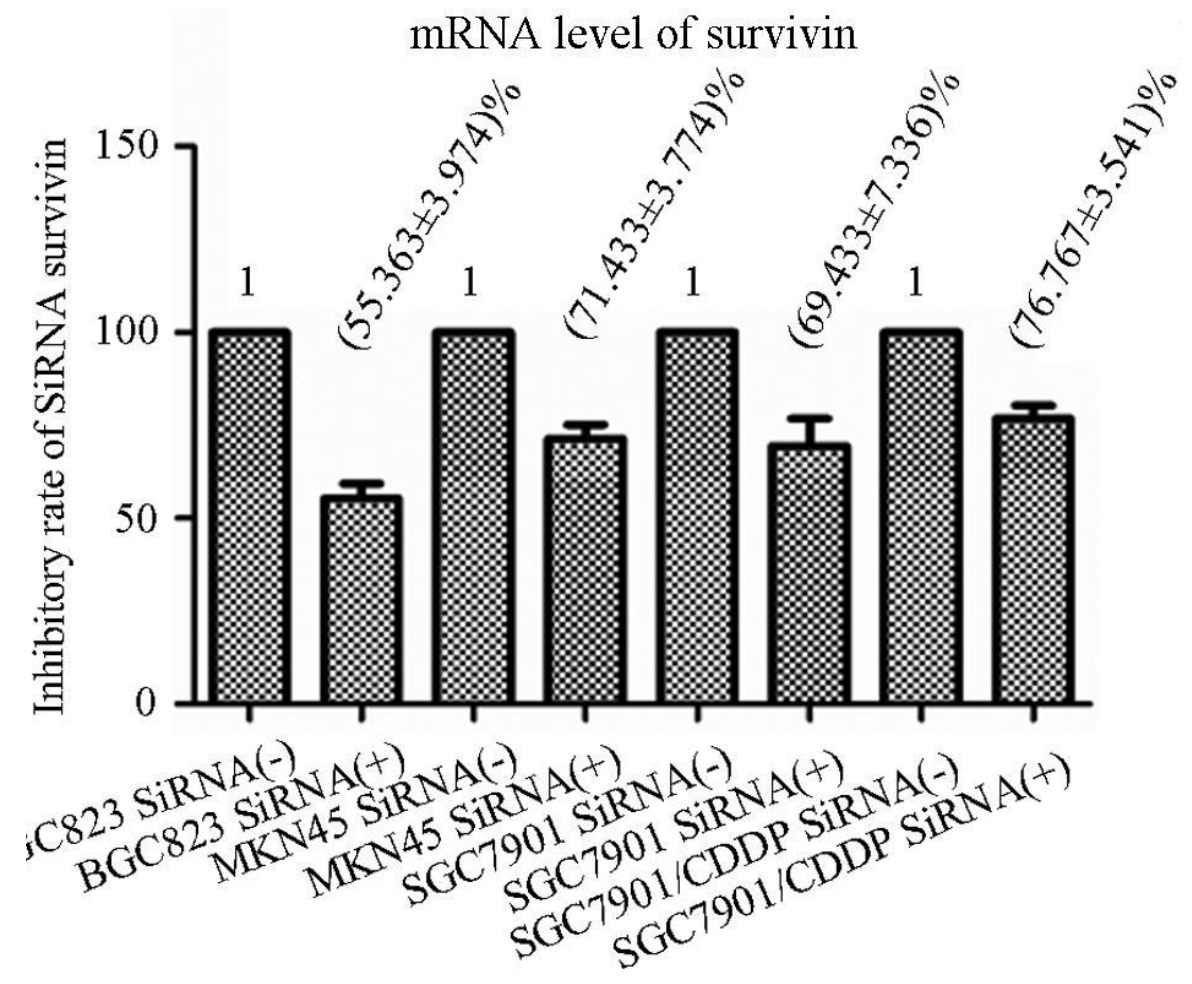

Figure 1. Effects of siRNA-survivin interference on survivin mRNA expression and cell proliferation (survivin mRNA level). 


\section{Survivin protein expression}

Survivin protein expression was detected after 48-h interference with siRNA. The results showed that siRNA-survivin had noticeably inhibitory effects on survivin protein expression in the four cell strains. For MKN45, the relative optical density (OD) value of the survivin protein expression after positive interference was $0.453 \pm 0.019$, whereas that after negative interference was $0.541 \pm 0.019$. For BGC823, the relative OD value of the survivin protein expression after positive interference was $0.293 \pm 0.017$, whereas that after negative interference was $0.453 \pm$ 0.019 . For SGC7901, the relative OD value after positive interference was $1.114 \pm 0.025$, whereas that after negative interference was $1.678 \pm 0.035$. For cisplatin-resistant SGC7901, the relative OD value of the survivin protein expression after positive interference was $1.678 \pm 0.034$, whereas that after negative interference was $1.831 \pm 0.093$. All cell strains showed significant differences in OD values after positive and negative interference $(\mathrm{P}<0.05)$. The results are shown in Figure 2.

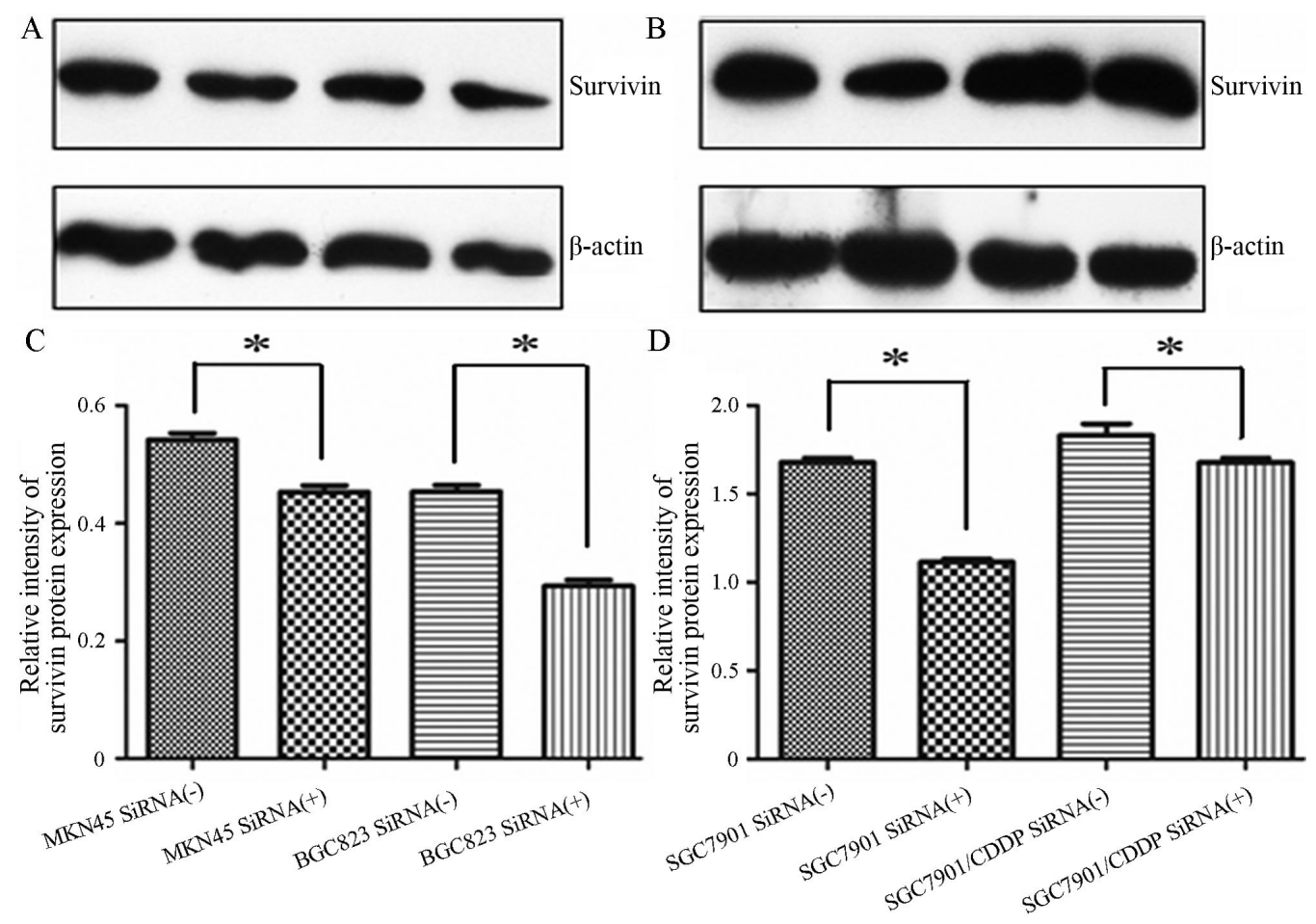

Figure 2. Effects of siRNA-survivin interference on survivin protein expression in the four GC cell strains $(* \mathrm{P}<0.05)$.

\section{Intracellular survivin protein localization}

As shown in Figure 3, intracellular survivin protein location changed in all the GC cells strains after $48 \mathrm{~h}$ of siRNA-survivin interference. Before interference, survivin was primarily localized in nucleus. After interference, intranuclear survivin markedly decreased. This finding indicated the effective interference of siRNA-survivin. 


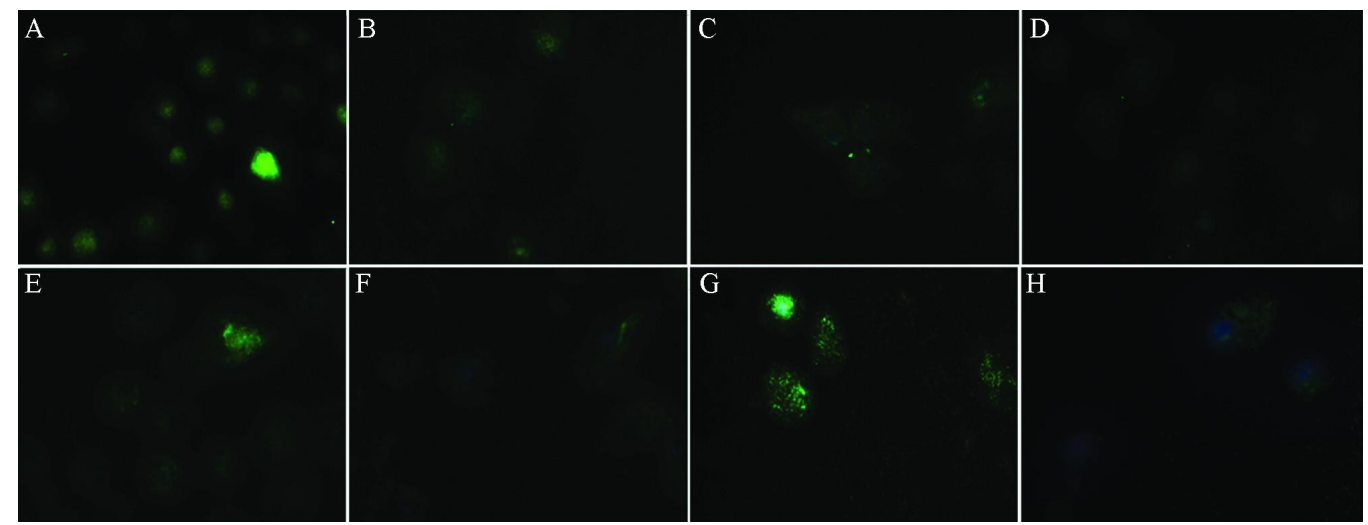

Figure 3. Effects of siRNA-survivin interference on the intercellular survivin protein localization in BGC823, MKN45, SGC7901, and SGC7901/CDDP. A. BGC823 siRNA (-). B. BGC823 siRNA (+). C. MKN45 siRNA (-). D. MKN45 siRNA (+). E. SGC7901 siRNA (-). F. SGC7901 siRNA (+). G. SGC7901/CDDP siRNA (-). H. SGC7901/CDDP siRNA (+).

\section{Cell apoptosis}

Cell apoptosis after siRNA interference in survivin expression was observed using flow cytometry. The results showed that after siRNA-survivin interference, the apoptosis of the four strains noticeably increased, particularly early apoptosis. In the MKN45 group, the early apoptotic rate after positive interference was $10.3 \%$, whereas that after negative interference was $7.2 \%$. In the BGC 823 group, the early apoptotic rate after positive interference was $22.5 \%$, whereas that after negative interference was 3.4\%. In the SGC7901 group, the early apoptotic rate after positive interference was $12.3 \%$, whereas that after negative interference was $6.9 \%$. In the cisplatin-resistant SGC7901 group, the early apoptotic rate after positive interference was $35.4 \%$, whereas that after negative interference was $26.1 \%$. The results are shown in Figure 4.

\section{Cell proliferation}

Cell proliferation after siRNA-survivin interference was detected using CCK-8 kits. The results showed that cell proliferation of the four GC cell strains was significantly inhibited (Figure 5). In the BGC823 group, the OD value after positive interference was $0.511 \pm 0.043$, whereas that after negative interference was $0.802 \pm 0.178(\mathrm{P}<0.05)$. In the MKN45 group, the OD value after positive interference was $0.701 \pm 0.099$, whereas that after negative interference was $0.775 \pm 0.133(\mathrm{P}<0.05)$. In the MKN45 group, the OD value after positive interference was $0.701 \pm 0.099$ and that after negative interference was $0.775 \pm 0.133(\mathrm{P}>0.05)$. In the SGC7901 group, the OD value after positive interference was $0.384 \pm 0.079$ and that after negative interference was $0.400 \pm 0.041(\mathrm{P}>0.05)$. In the cisplatin-resistant $\mathrm{SGC7901}$ group, the OD value after positive interference was $0.301 \pm 0.014$ and that after negative interference was $0.372 \pm 0.027(\mathrm{P}>0.05)$. 
A

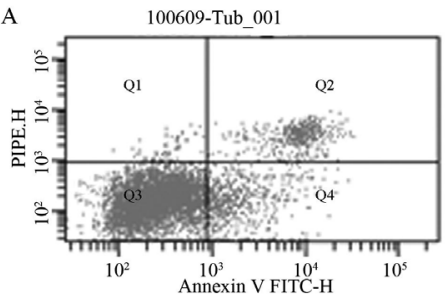

$\mathrm{C}$

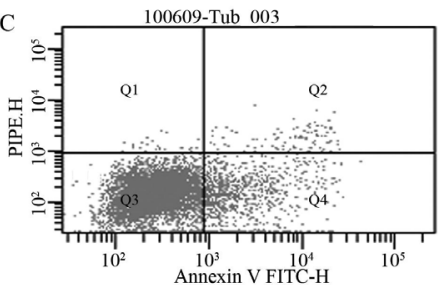

E
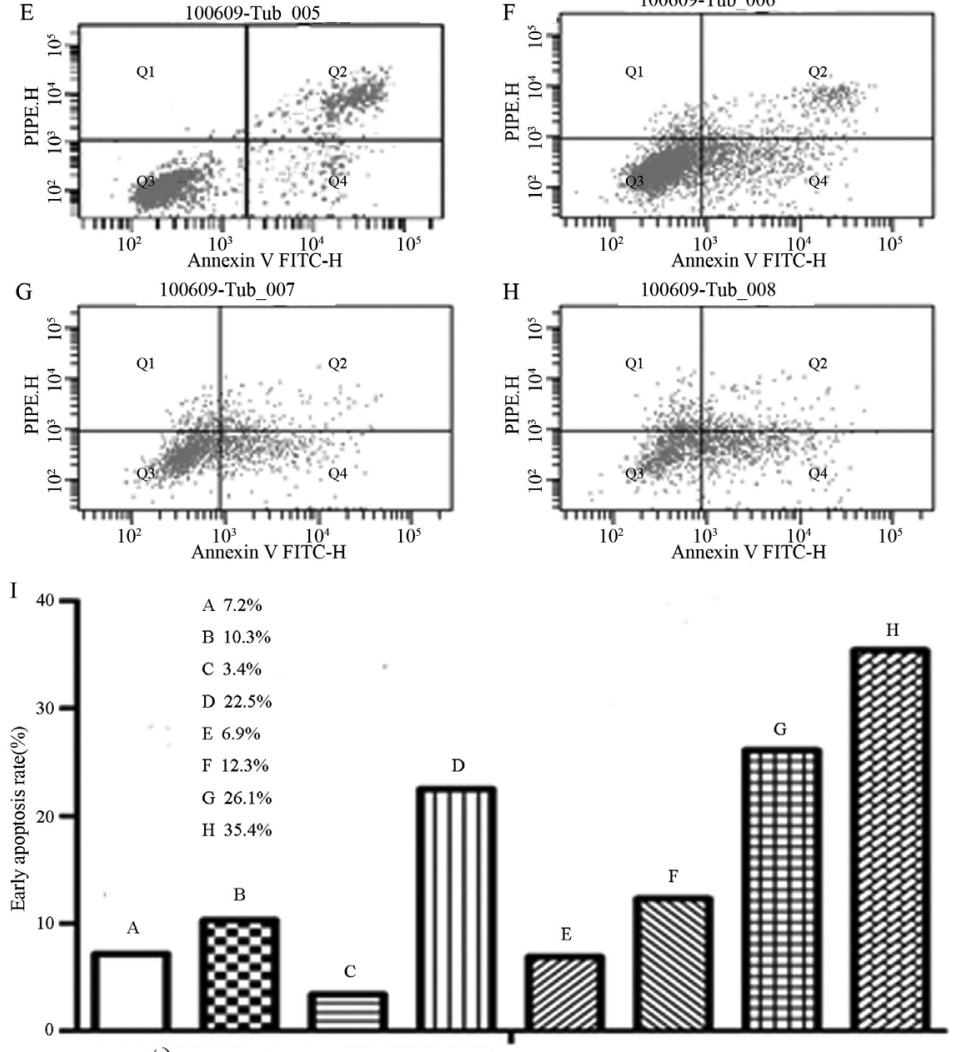
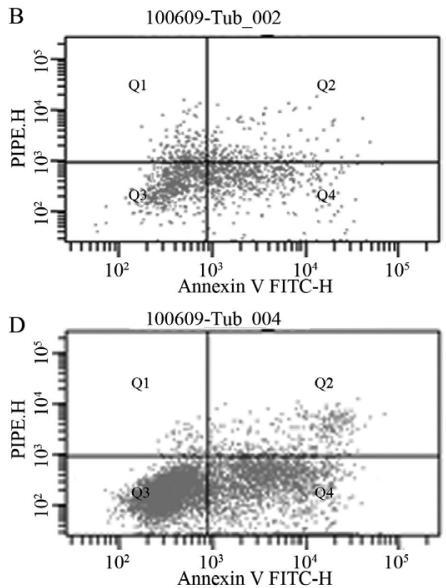

F 100609-Tub_006

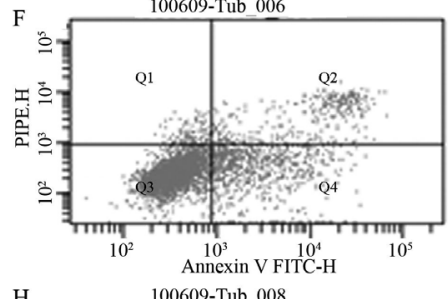

H 100609-Tub 008

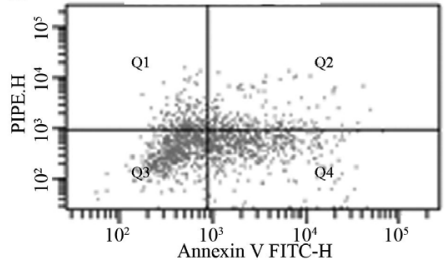

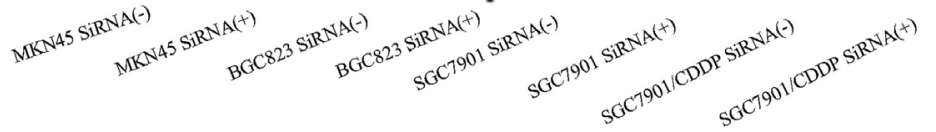

Figure 4. Effects of siRNA-survivin interference on early cell apoptosis of BGC823, MKN45, SGC7901, and SGC7901/CDDP. A. MKN45 siRNA (-). B. MKN45 siRNA (+). C. BGC823 siRNA (-). D. BGC823 siRNA (+). E. SGC7901 siRNA (-). F. SGC7901 siRNA (+). G. SGC7901/CDDP siRNA (-). H. SGC7901/CDDP siRNA (+). 


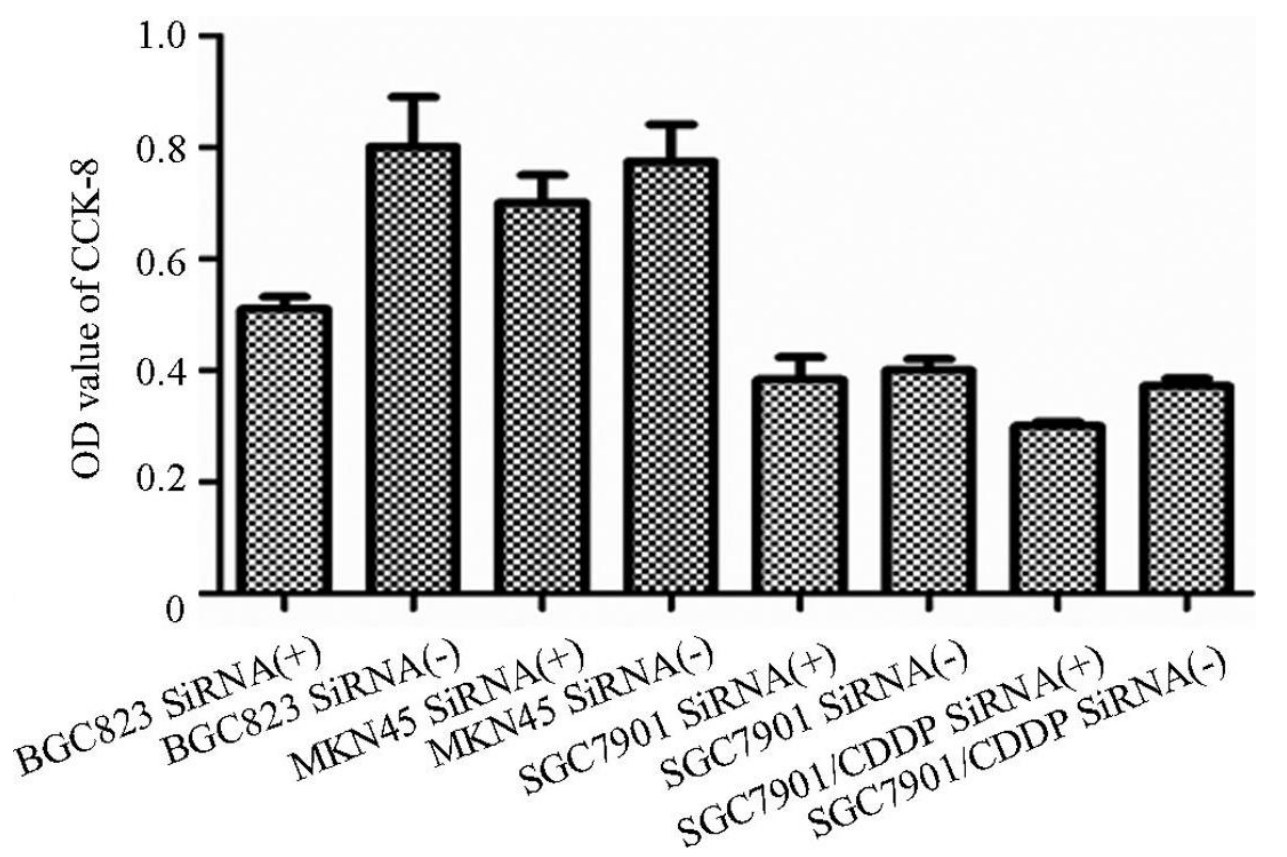

Figure 5. Effects of siRNA-survivin interference on survivin mRNA expression and cell proliferation (changes in cell proliferation).

\section{SiRNA (+)/siRNA (-) ratios}

With the siRNA (+)/siRNA (-) ratio as the ordinate, the ratios between the survivin mRNA levels, protein levels, and OD values after positive and negative interference were localized for comparison. The results showed that siRNA-survivin had the best interference effect on BGC823, which was followed by SGC7901 (Figure 6A). With the siRNA (+)/siRNA $(-)$ ratio as the ordinate, the ratio between the early apoptotic rates after positive and negative interference were localized. The results showed that siRNA-survivin had a better early apoptosis-promoting effect on BGC823 than any other cell strain. The results are shown in Figure 6B.

\section{Caspase-3 protein}

As shown in Figure 7, after 48-h siRNA interference, caspase-3 protein expression significantly increased in all four siRNA-survivin interfered cell groups compared with those in their corresponding negative control groups. This finding demonstrated that interference in survivin expression upregulated caspase-3 expression to some degree.

\section{Mitochondrial and cytoplasmic cytochrome C}

The relative OD values of the mitochondrial cytochrome $\mathrm{C}$ protein expression in the positively interfered BGC823, MKN45, SGC7901, and SGC7901/CDDP were 0.353 
$\pm 0.017,0.821 \pm 0.106,0.501 \pm 0.097$, and $0.369 \pm 0.060$, whereas those in the negative control cell strains were $1.383 \pm 0.087,1.093 \pm 0.042,0.709 \pm 0.109$, and $1.024 \pm 0.059$, respectively, which showed significant differences $(\wedge \mathrm{P}<0.01$ and $* \mathrm{P}<0.05$; Figure 8 A, $\mathrm{B})$. These results indicated that siRNA-survivin significantly decreased mitochondrial cytochrome $\mathrm{C}$ protein expression. The relative $\mathrm{OD}$ values of the cytoplasmic cytochrome $\mathrm{C}$ protein expression in the positively interfered BGC823, MKN45, SGC7901, and SGC7901/ CDDP were $0.993 \pm 0.083,1.156 \pm 0.202,1.057 \pm 0.047$, and $1.078 \pm 0.066$, whereas those in the negative control cell strains were $0.255 \pm 0.061,0.850 \pm 0.062,0.328 \pm 0.061$, and $0.778 \pm 0.035$, respectively, which showed significant differences $(\mathrm{P}<0.01$ and $\mathrm{P}<0.05$; Figure 8C, D). These results indicated that siRNA-survivin significantly decreased cytoplasmic cytochrome $\mathrm{C}$ protein expression.
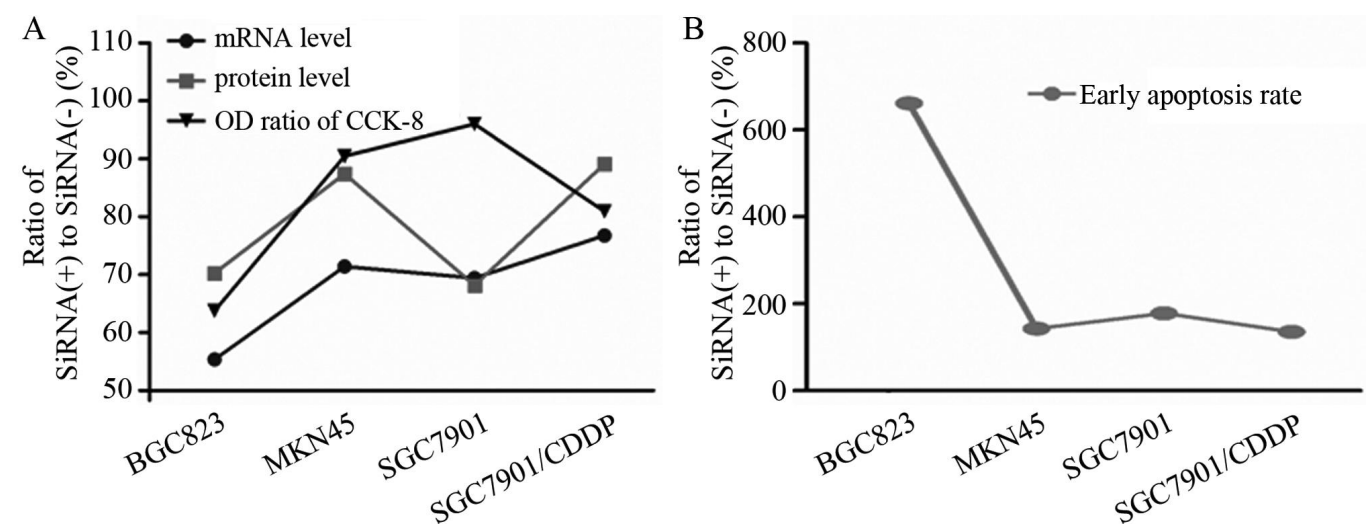

Figure 6. Comparisons of the mRNA levels, protein levels, relative OD values, and early apoptotic rates after positive [siRNA (+)] and negative [siRNA (-)] interference in the four GC cell strain groups. A. mRNA levels, protein levels, relative OD values, and early apoptotic rates after siRNA (+) and siRNA (-) interference. B. early apoptotic rates after siRNA (+) and siRNA (-) interference.

\section{pRNA-shSUR identification}

The interfering sequence was synthesized using the loop-stem structure tcaagag and identified by adding an EcoRI restriction enzyme cutting site (Figure 9A). pRNA-shSUR was digested by BamHI, EcoRI, and HindIII and then subjected to $0.8 \%$ agarose gel electrophoresis. The result showed only one specific band (Figure 9B). The macrorestriction map was identified correctly. After plasmid transfection, the GFP fluorescent expression increased in BGC823 and SGC7901 (Figure 9C-F).

pRNA-shSUR and liposomes were mixed and then transfected into the GC cells. At $48 \mathrm{~h}$, survivin protein expression in the cells was analyzed using Western blotting. The relative OD values of the survivin protein expression in BGC823 and SGC7901 after shRNA transfection were $0.116 \pm 0.021$ and $0.132 \pm 0.011$, whereas those after negative control plasmid transfection were $0.468 \pm 0.094$ and $0.156 \pm 0.037$, which showed significant differences $(\mathrm{P}<$ 0.01 and $\mathrm{P}<0.05$ : Figure 10 ). 


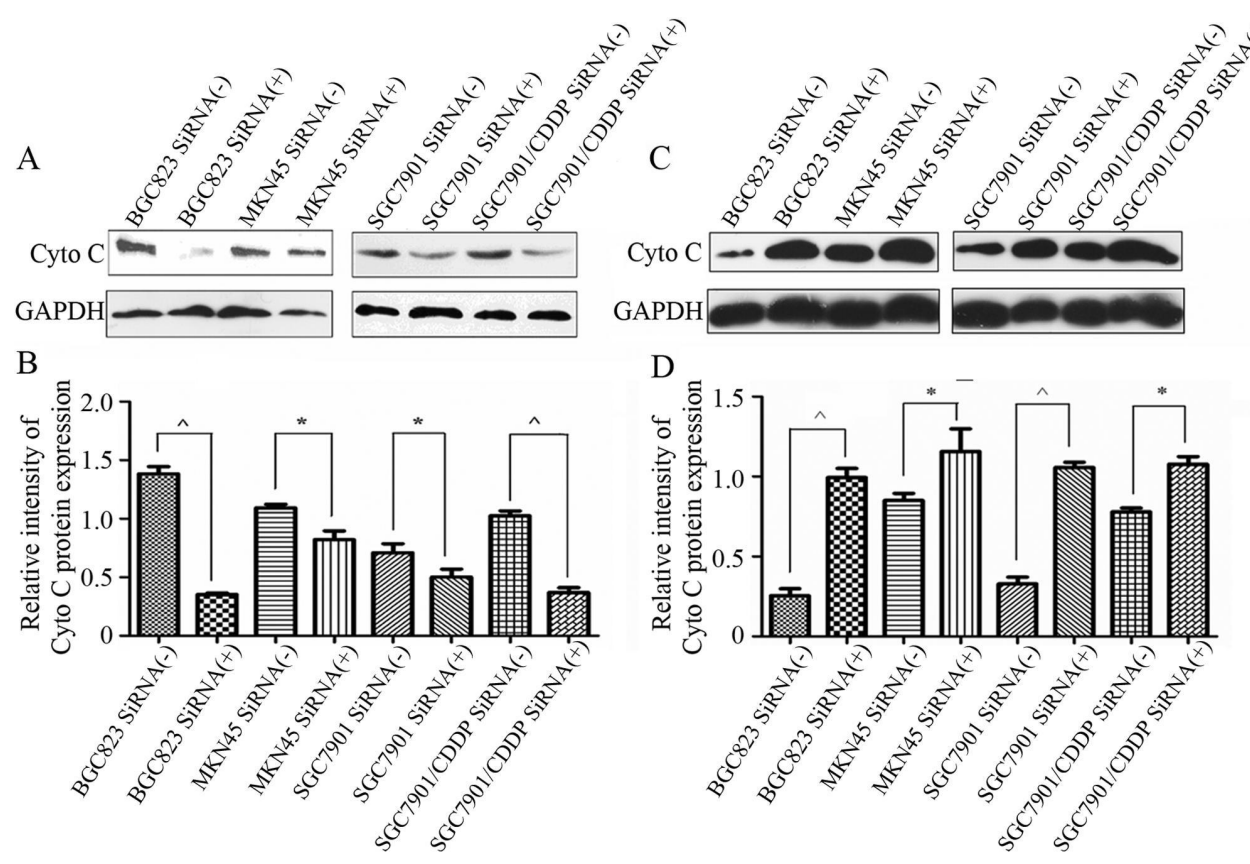

Figure 8. Effects of siRNA-survivin interference in survivin expression on mitochondrial and cytoplasmic cytochrome $\mathrm{C}$ protein expression $\left({ }^{\wedge} \mathrm{P}<0.01\right.$ and $\left.* \mathrm{P}<0.05\right)$. A. and $\mathrm{B}$. Mitochondrial cytochrome $\mathrm{C}$ protein expression, $\mathbf{C}$. and $\mathbf{D}$. cytoplasmic cytochrome $\mathrm{C}$ protein expression.

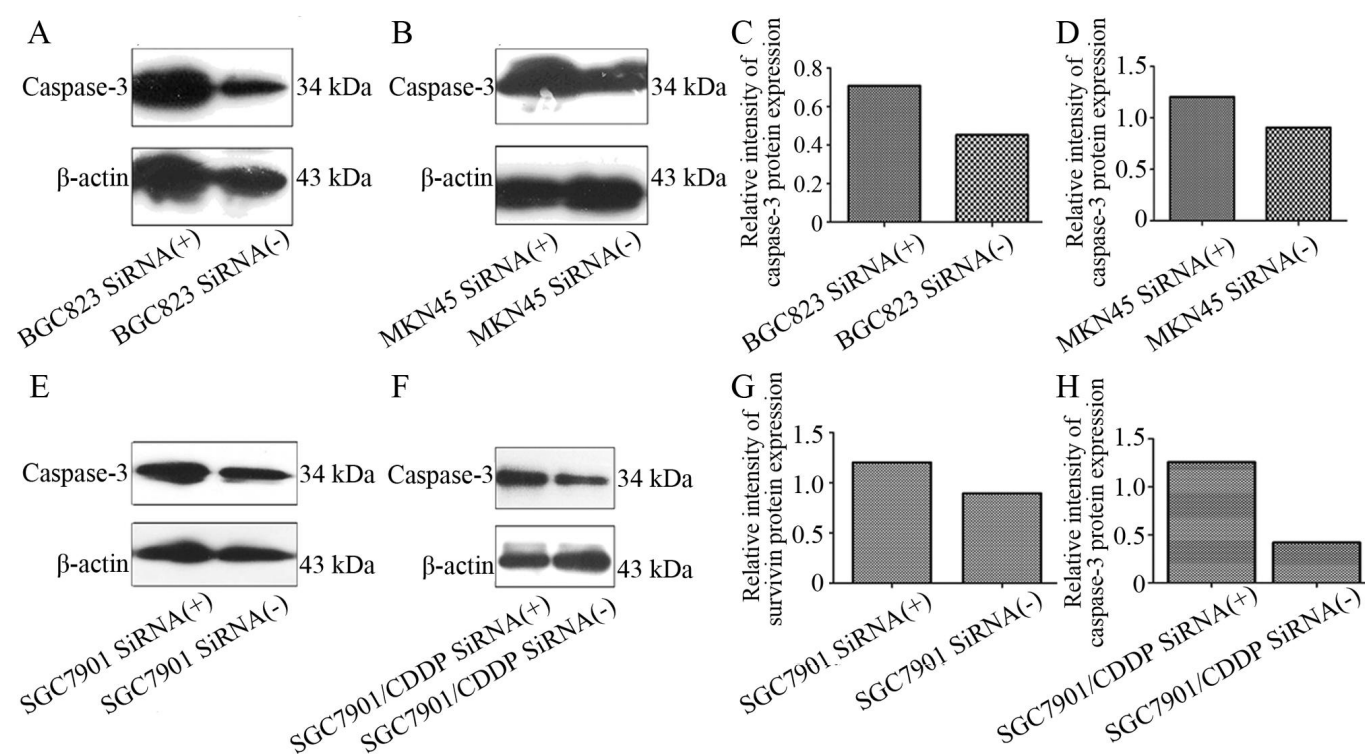

Figure 7. Effects of siRNA-survivin interference on caspase-3 protein in BGC823, MKN45, SGC7901, and SGC7901/CDDP. 

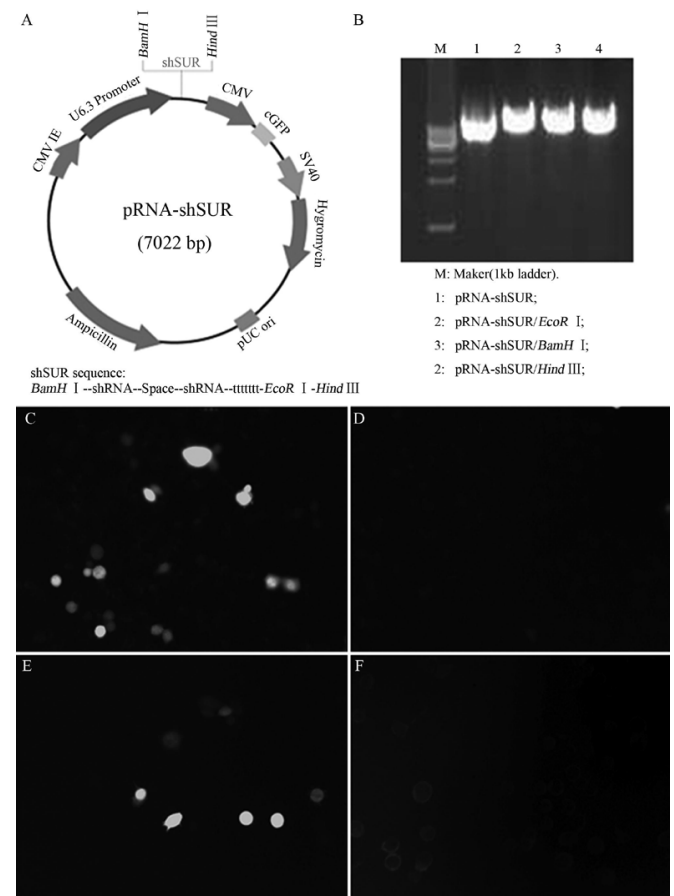

Figure 9. Structural schematic diagram (A), digestion identification (B), and post-transfection GFP identification (C-F) of the recombinant plasmid pRNA-shSUR. A. the structural schematic diagram of pRNA-shSUR. B. digestion identification. C. BGC823 after pRNA-shSUR transfection. D. BGC823 after pRNA-shControl transfection. E. SGC7901 after pRNA-shSUR transfection. F. SGC7901 after pRNA-shControl transfection.

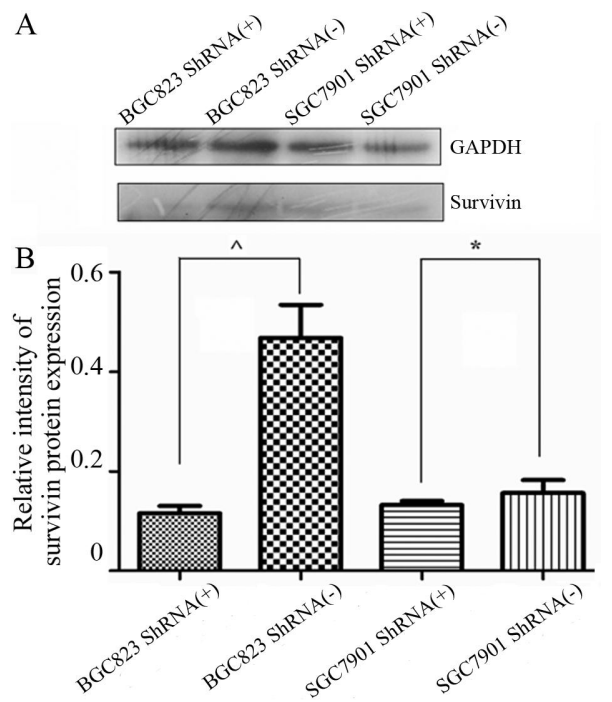

Figure 10. Effect of pRNA-shSUR transfection on survivin protein expression in the GC cell strains $\left({ }^{\wedge} \mathrm{P}<0.01\right.$ and $* \mathrm{P}<0.05)$. 


\section{DISCUSSION}

Tumorigenesis is a multiple-link process underlying which oncogene activation functions as a critical pathological mechanism. Therefore, specific anti-oncogene activation has become an important research direction of oncotherapy. Considering that RNAi technique has the characteristics of high efficiency and strict sequence specificity, we designed specific oncogenedirected siRNA molecules in this study. These molecules were expected to act on abnormal genes rather than normal genes, thereby realizing the aim of tumor treatment. Brummmelkamp et al. (2002) once constructed the siRNA expression system of the mutant K-RASV12, namely, pSUPER-K-RASV12. They transfected it into the human pancreatic cancer CAPAN-1 cell strain and observed its inhibitory effect on the expression of endogenous K-RASV12. Their results showed that pSUPER-K-RASV12 noticeably decreased K-RASV12 mRNA expression but had no influence on the expression of cyclin D1 (the control). K-RASV12 carrying siRNA noticeably inhibited the cloning and growth of CAPAN-1 cells and prevented tumorigenesis in nude mice, whereas it promoted cell growth and cloning in the control group and tumorigenesis occurred in nude mice within 5 weeks. Their findings indicated that siRNA had remarkable specificity and inhibitory effect on tumorigenesis, and can thus provide a new technical scheme for tumor research.

Survivin has the functions of regulating cell cycle and inhibiting cell apoptosis. survivin is not expressed in G1 phase; its expression increases six times in S phase and 40 times in G2/M phase (Li et al., 1998). This finding suggested that it is primarily expressed in $\mathrm{G} 2 / \mathrm{M}$ phase and serves as a regulatory gene in this phase. This characteristic of survivin is attributed to three cell cycle-dependent elements (CDEs) and a cell cycle homology region (CHR) among its primers. CDEs and CHR belong to suppression elements in G1 phase, and they regulate the half-life of gene expression in $\mathrm{G} 2 / \mathrm{M}$ phase, which enable survivin to be specifically expressed in G2/M phase. Survivin regulation is correlated with cell cycle-related

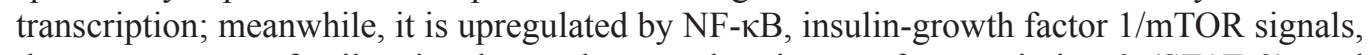
the ras oncogene family, signal transducer and activator of transcription 3 (STAT 3), and wnt-2 (Van Antwerp et al., 1998; Sommer et al., 2003; You et al., 2004; Vaira et al., 2007); furthermore, its regulation correlates with its intracellular localization and the generation of different spliceosomes during translation. Survivin has two types of subcellular locations, namely, intranuclear and/or intracytoplasmic (Fortugno et al., 2002). This distributional difference is caused by different post-transcriptional modifications of survivin. The selective splicing of survivin pre-mRNA can generate different splicing isoforms, and total length of survivin, survivin-2B, and survivin- $\Delta$ Ex-3 are the three known isoforms. However, the functions of survivin isoforms in different tumors remain to be explored.

Numerous studies of survivin expression in tumors have been reported (Altieri, 2003a). Survivin increases the resistance of tumor cells to apoptosis signals through caspasedependent or non-dependent channels, thereby blocking apoptosis; conversely, tumor cell antagonizing survivin leads to apoptosis (Ambrosini et al., 1997; Li et al., 1998; Altieri, 2003a,b).

Survivin decomposition in HeLa cells causes abnormal mitoses and polyploidy ( $\mathrm{Li}$ et al., 1999), whereas survivin knock-out mice suffer from early abortion due to microtubule constitution disorders and polyploid formation (Uren et al., 2000). Studies have shown that survivin overexpression correlates with the increase in proliferation index (Sui et al., 2002; Takai et al., 2002; Fields et al., 2004; Morinaga et al., 2004), decrease in apoptosis rate (Kawasaki et al., 1998; Tanaka et al., 2000), chemotherapeutic drug administration (Tran et al., 2002; 
Zaffaroni et al., 2002), and tumor recurrence (Swana et al., 1999).

A number of studies have shown that survivin is noticeably overexpressed in GC tissue (Tsuburaya et al., 2002; Li et al., 2004; Lu and Liu, 2004). Furthermore, the GC apoptotic index in the survivin-positive group is significantly lower than that in the negative group, and survivin expression correlates with the differentiation and pathological staging of GC tissue, which suggest that an increase in survivin may serve as a clue for poor prognosis of GC (Li et al., 2004). However, some authors disagree with these findings (Okada et al., 2001). These inconsistencies may be ascribed to differences in survivin protein detection methods and intracellular localization or different spliceosomes involved. Survivin expression in surgical specimens is associated with the size, invasion depth, lymphatic metastasis, staging and prognosis of tumors; furthermore, survivin plays an important role in tumorigenesis by stimulating tumor angiogenesis (Lee et al., 2006). Survivin is overexpressed in tumor cells while almost not expressed in normal tissues, which determines the survivin gene as a suitable target for tumor treatment.

survivin-targeting double-stranded RNA noticeably reduces mRNA transcription and translation of survivin and decreases survivin protein expression in the pancreatic cancer cell line PANC-1, thereby resulting in cell apoptosis, whereas it has no noticeable influence on the cell cycle (Tsuji et al., 2005).

Based on the aforementioned findings, we constructed a double-stranded siRNA and then transfected it into GC cell strains. The results of real-time PCR showed that siRNA interfered with the mRNA levels in all the cell lines investigated. For BGC823, the mRNA level after siRNA-survivin positive interference was $55.363 \pm 3.974 \%$ of that after negative interference; for MKN45, the mRNA level after positive interference was $71.433 \pm 3.774 \%$ of that after negative interference; and for SGC7901 and cisplatin-resistant SGC7901, the mRNA levels after positive interference were $69.433 \pm 7.336$ and $76.767 \pm 3.541 \%$ of those after negative interference, respectively. These findings suggest that the synthesized siRNA markedly decomposed survivin mRNA in this study, and prove that the designed and synthesized double-stranded RNA was valid.

Immunoblotting was then performed. For BGC823, the relative OD value of survivin protein expression after positive interference was $0.293 \pm 0.017$, whereas that after negative interference was $0.453 \pm 0.019$; for MKN45, SGC7901, and cisplatin-resistant SGC7901, the OD values after positive interference were $0.453 \pm 0.019,1.114 \pm 0.025$, and $1.678 \pm 0.034$, whereas those after negative interference were $0.541 \pm 0.019,1.678 \pm 0.035$, and $1.831 \pm$ 0.093 , respectively. Significant differences were observed in all the groups after positive and negative interference $(\mathrm{P}<0.05)$. This finding was also evident in the immunofluorescence results: survivin protein was expressed in nuclei; however, after siRNA interference, intranuclear survivin protein expression significantly decreased.

The primary function of survivin expression in tumor cells is to antagonize cell apoptosis. In this study, flow cytometry was performed using Annexin V-FITC-PI double staining kits. The results showed that the biological behaviors of GC changed after interference with survivin expression: for BGC823, the early apoptotic rate after positive interference was $22.5 \%$, whereas that after negative interference was 3.4\%; for MKN45, SGC7901, and cisplatin-resistant SGC7901, the early apoptotic rates after positive interference were 10.3, 12.3, and $35.4 \%$, whereas those after negative interference were $7.2,6.9$ and $26.1 \%$, respectively. These results suggest that the RNAi technique promoted noticeable GC cell apoptosis by interfering with survivin expression. 
Miao et al. (2007) successfully interfered with survivin protein expression in the GC cell strain SGC7901 using siRNA; they also found that the inhibition of GC cell growth was correlated with the GC cell apoptosis-inducing effect of siRNA in vitro. Ma et al. (2007) found that survivin-targeting antisense oligonucleotides did not only induce the apoptosis of SGC7901 but also increased its sensitivity to paclitaxel.

The anti-cell apoptosis mechanism of survivin is realized by inhibiting the activation of caspase-3 and caspase-7. Caspases are a group of cysteine-containing proteases that promote cell apoptosis. Their enzymatic substrates include themselves and other factors. They transduce apoptosis signals or directly serve as apoptosis effector molecules by hydrolyzing their substrates to promote cytoskeleton degradation and DNA fragmentation. Normally, most capspases exist in the form of inactive precursors, namely, caspase proenzymes. The activation of these proenzymes is usually caused by the upper stage of caspase splicing, forming a cascade effect; therefore, they are autocatalyzed (Altieri, 2001; Wakana et al., 2002). The usual channel whereby caspases cause cell apoptosis is the receipt of dead signals by dead receptors, which causes the activation of the upstream procaspase- 8 and leads to the activation of procaspase-9. These processes ultimately result in cytoarchitectonic damage. Survivin inhibits the caspase activation induced by cytochrome $\mathrm{C}$ or caspase-8, and also prevents caspase-3 and caspase-7 (Kania et al., 2003). Therefore, survivin overexpression in GC inhibits cell apoptosis or promotes mitosis, which benefits the survival and growth of tumor cells.

Cytochrome $\mathrm{C}$ was previously assumed to primarily participate in controlling cellular energy metabolism. Recently, it has been thought as an important factor participating in apoptosis. The loss of mitochondrial respiratory activity is only part of its participation in apoptosis. What is more important is its release from mitochondria. Normally, cytochrome $\mathrm{C}$ is a water-soluble protein located in the mitochondrial membrane space with a relative molecular mass of $1.45 \times 10^{4}$. It binds the mitochondrial inner membrane in an electrically stable manner and cannot penetrate through the outer membrane. During apoptosis, cytochrome $\mathrm{C}$ is released through the mitochondrial outer membrane, and afterwards binds to apoptotic protease activating factor-1 (Apaf-1) through ATP/dATP to form oligomers. Apaf-1 interacts with the anterior region of procaspase- 9 via the amino terminal of the oligomer to activate caspase- 3 and downstream caspases. In this study, after survivin in GC cells was interfered, the cytochrome $\mathrm{C}$ level in mitochondria decreased, whereas that in cytoplasm increased. Presumably, survivintargeting interference causes the release of cytochrome $\mathrm{C}$ from mitochondria into cytoplasm, as well as an increase in caspase-3 protein expression, which indicates that survivin-targeting siRNA promotes GC cell apoptosis through the classic mitochondrial pathway.

Abnormal cell proliferation occupies an equally important position with abnormal apoptosis in the genesis of tumors, and malignant tumor cells display reproductive activity as vigorous as embryonic tissues. Survivin has a cell proliferation-promoting function. Sui et al. (2002) analyzed 103 cases of ovarian neoplasms to explore the influence of survivin expression on cell proliferation and curative effect of tumors. They found that the survivin positive rates in malignant and borderline tumors were significantly higher than that in benign tumors (the detection rates were $21.2,47.8$ and $51.1 \%$, respectively); survivin expression positively correlated with the activity of tumor cell proliferation; its overexpression plays critical roles in both the development and prognosis prediction of ovarian neoplasm. Survivin is positively expressed in $88 \%$ (46/52) of patients with pancreatic cancer; it is closely correlated with tumor cell proliferation and growth; the cell proliferation index in the survivin-positive group is sig- 
nificantly higher than that in the negative group (Sarela et al., 2002). Survivin-targeting mixed double-stranded RNA inhibits the tumor progression in animals transplanted with rhabdomyosarcoma, suggesting a possible gene therapeutic effect (Caldas et al., 2006).

In addition, the results of the CCK-8 experimental in this study proved that interference in survivin expression can further inhibit the reproductive activity of GC cells. The results of cytometry showed survivin-targeting siRNA vectors induced the early apoptosis of the four cell strains investigated in this study. Thus, this study successfully proved the validity and early cell apoptosis-promoting effect of survivin-targeting siRNA vectors from multiple perspectives.

Tumorigenesis is a process involving numerous factors. Survivin overexpression in tumor cells noticeably inhibits cell apoptosis and allows tumor cells to avoid identification and removal by the immune system. Survivin possesses high conservation and a cell apoptosis inhibiting role. Therefore, it can only provide a new research direction for tumor treatment in expression specificity in tumor cells. survivin is a newly discovered anti-apoptosis gene. It promotes tumor cell proliferation, playing an important role in the development of tumors. As survivin is selectively expressed in tumor tissues, it may serve as a specific target to open up a new path to tumor gene therapy.

\section{ACKNOWLEDGMENTS}

Research supported by the Jiangsu Provincial National Scientific Grant (\#BK2007005) and the National Scientific Foundation Grant (\#81101814 and \#81272742).

\section{REFERENCES}

Altieri DC (2001). The molecular basis and potential role of survivin in cancer diagnosis and therapy. Trends Mol. Med. 7: $542-547$.

Altieri DC (2003a). Survivin, versatile modulation of cell division and apoptosis in cancer. Oncogene 22: 8581-8589.

Altieri DC (2003b). Validating survivin as a cancer therapeutic target. Nat. Ver. Cancer 3: 46-54.

Ambrosini G, Adida C and Altieri DC (1997). A novel anti-apoptosis gene, survivin, expressed in cancer and lymphoma. Nat. Med. 3: 917-921.

Brummelkamp TR, Bernards R and Agami R (2002). Stable suppression of tumorigenicity by virus-mediated RNA interference. Cancer Cell 2: 243-247.

Caldas H, Holloway MP, Hall BM, Qualman SJ, et al. (2006). Survivin-directed RNA interference cocktail is a potent suppressor of tumour growth in vivo. J. Med. Genet. 43: 119-128.

Fields AC, Cotsonis G, Sexton D, Santoianni R, et al. (2004). Survivin expression in hepatocellular carcinoma: correlation with proliferation, prognostic parameters, and outcome. Mod. Pathol. 17: 1378-1385.

Fortugno P, Wall NR, Giodini A, O'Connor DS, et al. (2002). Survivin exists in immunochemically distinct subcellular pools and is involved in spindle microtubule function. J. Cell Sci. 115: 575-585.

Kania J, Konturek SJ, Marlicz K, Hahn EG, et al. (2003). Expression of survivin and caspase-3 in gastric cancer. Dig. Dis. Sci. 48: 266-271

Kawasaki H, Altieri DC, Lu CD, Toyoda M, et al. (1998). Inhibition of apoptosis by survivin predicts shorter survival rates in colorectal cancer. Cancer Res. 58: 5071-5074.

Lee GH, Joo YE, Koh YS, Chung IJ, et al. (2006). Expression of survivin in gastric cancer and its relationship with tumor angiogenesis. Eur. J. Gastroenterol. Hepatol. 18: 957-963.

Li F, Ambrosini G, Chu EY, Plescia J, et al. (1998). Control of apoptosis and mitotic spindle checkpoint by survivin. Nature 396: 580-584.

Li F, Ackermann EJ, Bennett CF, Rothermel AL, et al. (1999). Pleiotropic cell-division defects and apoptosis induced by interference with survivin function. Nat. Cell Biol. 1: 461-466. 
Li YH, Wang C, Meng K, Chen LB, et al. (2004). Influence of survivin and caspase-3 on cell apoptosis and prognosis in gastric carcinoma. World J. Gastroenterol. 10: 1984-1988.

Lu XY and Liu NZ (2004). Expression of Survivin Gene and its relationship with Expression of caspase-3, p53 in Gastric Carcinoma. J. Huazhong Univ. Sci. Technol. 33: 724-725.

Ma R, Chen XH, Zhang QF, Zhu L, et al. (2007). Exploration on the increased sensitivity to docetaxel and reversing mechanism of drug resistance of antisense survivin RNA in gastric cancer cell line SGC7901 cells. Zhonghua Zhong Liu Za Zhi 29: 89-92.

Miao GY, Lu QM and Zhang XL (2007). Downregulation of survivin by RNAi inhibits growth of human gastric carcinoma cells. World J. Gastroenterol. 13: 1170-1174.

Morinaga S, Nakamura Y, Ishiwa N, Yoshikawa T, et al. (2004). Expression of survivin mRNA associates with apoptosis, proliferation and histologically aggressive features in hepatocellular carcinoma. Oncol. Rep. 12: 1189-1194.

Nakamura M, Tsuji N, Asanuma K, Kobayashi D, et al. (2004). Survivin as a predictor of cis-diamminedichloroplatinum sensitivity in gastric cancer patients. Cancer Sci. 95: 44-51.

Okada E, Murai Y, Matsui K, Isizawa S, et al. (2001). Survivin expression in tumor cell nuclei is predictive of a favorable prognosis in gastric cancer patients. Cancer Lett. 163: 109-116.

Sarela AI, Verbeke CS, Ramsdale J, Davies CL, et al. (2002). Expression of survivin, a novel inhibitor of apoptosis and cell cycle regulatory protein, in pancreatic adenocarcinoma. Br. J. Cancer 86: 886-892.

Sommer KW, Schamberger CJ, Schmidt GE, Sasgary S, et al. (2003). Inhibitor of apoptosis protein (IAP) survivin is upregulated by oncogenic c-H-Ras. Oncogene 22: 4266-4280.

Sui L, Dong Y, Ohno M, Watanabe Y, et al. (2002). Survivin expression and its correlation with cell proliferation and prognosis in epithelial ovarian tumors. Int. J. Oncol. 21: 315-320.

Swana HS, Grossman D, Anthony JN, Weiss RM, et al. (1999). Tumor content of the antiapoptosis molecule survivin and recurrence of bladder cancer. N. Engl. J. Med. 341: 452-453.

Takai N, Miyazaki T, Nishida M, Nasu K, et al. (2002). Survivin expression correlates with clinical stage, histological grade, invasive behavior and survival rate in endometrial carcinoma. Cancer Lett. 184: 105-116.

Tanaka K, Iwamoto S, Gon G, Nohara T, et al. (2000). Expression of survivin and its relationship to loss of apoptosis in breast carcinomas. Clin. Cancer Res. 6: 127-134.

Tran J, Master Z, Yu JL, Rak J, et al. (2002). A role for survivin in chemoresistance of endothelial cells mediated by VEGF. Proc. Natl. Acad. Sci. U. S. A. 99: 4349-4354.

Tsuburaya A, Noguchi Y, Yoshikawa T, Saito A, et al. (2002). An anti-apoptosis gene, survivin and telomerase expression in gastric cancer. Hepatogastroenterology 49: 1150-1152.

Tsuji N, Asanuma K, Kobayashi D, Yagihashi A, et al. (2005). Introduction of a survivin gene-specific small inhibitory RNA inhibits growth of pancreatic cancer cells. Anticancer Res. 25: 3967-3972.

Uren AG, Wong L, Pakusch M, Fowler KJ, et al. (2000). Survivin and the inner centromere protein INCENP show similar cell-cycle localization and gene knockout phenotype. Curr. Biol. 10: 1319-1328.

Vaira V, Lee CW, Goel HL, Bosari S, et al. (2007). Regulation of survivin expression by IGF-1/mTOR signaling. Oncogene 26: 2678-2684.

Van Antwerp DJ, Martin SJ, Verma IM and Green DR (1998). Inhibition of TNF-induced apoptosis by NF-kappa B. Trends Cell Biol. 8: 107-111.

Wakana Y, Kasuya K, Katayanagi S, Tsuchida A, et al. (2002). Effect of survivin on cell proliferation and apoptosis in gastric cancer. Oncol. Rep. 9: 1213-1218.

You L, He B, Xu Z, Uematsu K, et al. (2004). Inhibition of Wnt-2-mediated signaling induces programmed cell death in non-small-cell lung cancer cells. Oncogene 23: 6170-6174.

Zaffaroni N, Pennati M, Colella G, Perego P, et al. (2002). Expression of the anti-apoptotic gene survivin correlates with taxol resistance in human ovarian cancer. Cell Mol. Life Sci. 59: 1406-1412. 